\title{
“DON'T LET US TALK OF THAT ANYMORE": WHITMAN'S ESTRANGEMENT FROM THE COSTELLOE-SMITH FAMILY
}

\author{
JOANN P. KRIEG
}

IN THE SUMMER of 1891 Dr. Richard M. Bucke visited England on two matters of business: the possible manufacture there of a gas and water meter invented by his brother-in-law, and a volume of essays on Walt Whitman for which he hoped to find a publisher. While there, he made use of a letter of introduction provided by Whitman to meet Alfred Tennyson and visited some of Whitman's English friends. The circle of friends included the family of Robert Pearsall Smith (1827-1898) and his married daughter Mary Costelloe (pronounced with the accent on the first syllable), to whom Whitman had been close when the family lived in Pennsylvania. After visiting the Smiths and Costelloes in London, Bucke wrote to Whitman and Horace Traubel. His letters hint darkly at an alteration in their affections for Whitman and promise a fuller explanation to be given in person. ${ }^{1}$

Whitman had suspected such an alteration, for there had been no letters from any of the Smiths for four months prior to the doctor's visit. ${ }^{2}$ His suspicions gave rise to various speculations: perhaps his inadvertent omission of their names from a Lippincott's article that mentioned some of his ardent supporters, or perhaps evil stories, of the type he insisted had followed him for years, were circulating in England and had caused them to turn away (WWC 8:394-395). But when the doctor told Whitman in person the particulars of his encounters with various members of the family, there was still no definite answer as to why they had changed, only the fact that they had done so. Except for one very friendly letter subsequent to Bucke's visit, from the son Logan Smith, there was never again any exchange between the family and the poet. ${ }^{3}$

Bucke's letters and his report tell us just as much as Whitman ever knew of the matter, and the Smiths have existed for Whitman scholars mainly in footnotes that offer only sketchy outlines of this remarkable family. ${ }^{4}$ To Whitman, however, they loomed large, and the loss of their friendship hurt him deeply. With the recent publication of the final books of Horace Traubel's record of conversations with Whitman, we can gauge for the first time the depth of that hurt as we trace the poet's recurring references to the matter and his confusion concerning it. Traubel's ac- 
count of Bucke's report runs for almost four pages, describing Whitman as close to tears and finally bursting out, like Lear bemoaning Cordelia's banishment, "Don't let us talk of that anymore." 5 To Traubel he had already admitted that the matter was "painful," but he knew he had to put it behind him without mourning since there was "not a beam of light" by which he could illuminate it: "It is, I suppose, one of the several mysteries you fellows will one day, many days, have to clean up for me" (WWC 8:414).

Readers of Whitman's correspondence, his daybooks, and his conversations with Horace Traubel, can piece together the story of this aborted friendship but are left as bewildered as the poet himself was by its abrupt termination, unable to "clean up" the mystery. Only by venturing beyond the Whitman-related materials does one learn that the members of the Smith family authored at least forty published works and are the subjects of almost a dozen volumes. The attention that has been lavished on them by biographers is not undeserved for they were, for the most part, remarkable individuals, and the number and extent of their contacts with notable persons in England and on the continent foreshorten the now current adage that only six degrees of separation exist between any two supposed strangers. To enter the world of the Pearsall Smiths is to stumble unawares into the most select literary and political society of the modern period. But since our purpose here is to elucidate the break-up of the relationship between the Smiths and Whitman, we shall only tangentially trace Whitman's influence on some in the wide circle of their kindred and friends. As to method, it would seem most useful to follow Dr. Bucke's analytical mode and, using some of his own words, consider the possible motive of each member of the family for the change of heart that ended the friendship between the Smiths and Whitman, before revealing the actual cause.

\section{1. "The truth is, there is little change, except in Mrs. Costelloe."}

Mary Smith (1864-1945) — or, as the family preferred, Mary Whitall Smith-first read Leaves of Grass with no small degree of shock while studying at Smith College. There is a revealing glimpse of the way the book was passed from woman to woman in the 1880s in Mary's admission that it was one of her tutors who lent her the book, but with the caution not to speak of having read it. Mary piously informed her mother that, having been forewarned, she was able to avoid reading the worst parts. A few months later, however, she read the entire book and in a rush of enthusiasm began to extol its author in letters to her parents. Some years later, after she had married, Mary wrote in a letter to her mother how after reading Whitman she solemnly took as her motto, "Henceforth I ordain myself loosed of all limits and imaginary lines / Going where I list, my own Master, total and absolute."7 It was a motto she acted upon. 
Numerous published versions exist of how the first meeting between Whitman and the Smith family came about. One version, told by one of Mary's great granddaughters, says that Robert Smith had invited Whitman to lunch at their Germantown home in the suburbs of Philadelphia because he wished to please his daughter when she came home for a Christmas break. ${ }^{8}$ Mary's brother Logan, however, writing in 1937, remembers it as an Easter visit in 1882 that lasted a month! ${ }^{9}$ Henry Bryan Binns's 1905 biography of Whitman pays considerable attention to the friendship between Whitman and the Smith family, which may be the result of a personal acquaintance, since members of the family had by then been living in Binns's native England for some time. Binns claims that at Mary's insistence her father drove her to Camden, where Whitman, in the Stevens Street home of George and Louisa Whitman, received Mary's adulation "with a kindly, affectionate amusement."10 And, according to Binns, the invitation to come to Germantown that very day for an extended visit was spontaneously offered. Whitman is said to have yielded at least partly because of the handsome horse and carriage the Smiths had left waiting and which he glimpsed from the front window. A letter from Mary to her mother the following March, 1883, expresses her wish "to have W.W. one night with us," and recalls her excitement at going to meet him for the first time: "Theophile Gautier, when he first went to see Victor Hugo, fainted at his front doorstep. I did not faint on the marble steps of the little Camden house, but I shall never forget my feelings" (MB 25).

Whatever the circumstances of that first meeting, a short stay in Germantown at Christmas, 1882, followed by another at the arrival of the new year are indicated in Whitman's daybook and in his correspondence. ${ }^{11}$ They were the first of many such visits, one for as long as a month (which accounts for Logan Smith's remembrance), most instigated by Mary and her father, as in November of 1884 when Robert asked Mary what he could do to make her Thanksgiving vacation happy, and Mary responded, "Persuade Mr. Whitman to come over!" 12

Mary's mother, Hannah Whitall Smith (1832-1911), remained as disapproving of the poet of Leaves of Grass as she had been when she first warned her daughter against reading his work, claiming he "must be perfectly horrid as a man." Hannah's feelings about men-that they were generally "horrid"-led her to further counsel Mary against admitting to having read Whitman for fear she would incite "impure" thoughts of herself in the minds of "some young men." "If thee knew," she wrote, "more of men and their overpowering passions thee would understand how inflammatory such things as W.W. has written must necessarily be to many men, in fact to most."13 Mary defended her hero's morality by pointing out that "he means that the sexual act should never take place except with direct reference to the child who is to be 
the result. Thee will probably know more definitely than I how far this idea is ahead of most people, most married people" (MB 25).

Hannah was not placated by this, and it must have been difficult for her to sit at table in her own home with Whitman seated there in the company of her daughters, Mary and Alys. Perhaps her feelings were sufficiently communicated to her guest to cause him to eat lightly and then remove himself from the table to an adjoining hall where Mary remembered coaxing him to rejoin the company. He resisted her entreaties with the demur, "No, Mary, I love to hear you laugh, but I don't care about your conversation." ${ }^{14}$ It may have been that he truly did not care for the family conversation, which was sure to be about religion a good deal of the time. Mary recalled her mother once asking Whitman what he believed of God, a question he neatly sidestepped by having Mary answer for him based on her reading of his poems. Her response so pleased him that he avowed nothing had so "comforted" him in a long while. The comfort of Mary's answer was no doubt derived from the pleasure it gave him to have her so innocently foil her mother's attempt to trap him in a religious snare, laid perhaps in the hope of turning Mary against him.

It was Mary who dubbed the Charles Spieler photograph of Whitman (done around 1881) "the Lear photo," a designation that gave Whitman much delight (Corr. 4:197). In her diary Mary recalled the sixty-three year old Whitman as seeming much older at the time of his first visits to Germantown, with his silvery hair and slow gait heavily dependent on a cane. The house at 4653 Germantown Avenue was located in a neighborhood of prosperous Quaker businessmen and their families. It was large and imposing, with a "no-nonsense" look about it. Orderly and well-attended by Hannah Smith and a staff of servants, it was quite a contrast to the noisy, bustling atmosphere of the southern New Jersey home of Susan and George Stafford, where Whitman spent so many weeks and months between 1876 and 1884. The Staffords' tenant farm and house had been a welcome refuge from the gloom that overcast Walt's brother's home after the death of George and Louisa's infant son, but changing circumstances in the Stafford family had altered the mood of these visits, and Whitman was more than happy to avail himself of the comfort offered by the Smiths. ${ }^{15}$ He spoke to Horace Traubel of it, saying that the Smiths made their home "so much mine, its servants so much at my beck and call if I had wished it. The house could not have been more mine if I had owned it. . ." (WWC 1:172). Mary remembered him arriving often in his gray suit and once taking off the suit jacket to don a comfortable cardigan sweater. She and her sister and brother took great delight in listening to the poet sing loudly in the bath a variety of selections from spirituals to minstrel songs.

Mary's brother Logan once had the pleasure of an unexpected meeting with the poet in a Philadelphia bookstore. Because of his great 
interest in Whitman, the young man had ordered a copy of a book by Burroughs, probably Notes on Walt Whitman as Poet and Person (1867), and returned to the store hoping to find it. Instead, "there was the old gentleman himself," Logan wrote to Mary, "looking very natural."16 Some conversation ensued about Whitman's writings, especially Democratic Vistas, which Logan had enjoyed, and Whitman declared that Mary, Logan, and their friends were the only young people who understood him.

Mary's mother felt that she understood Whitman's writings well enough. Probably at the insistence of his wife, Robert Pearsall Smith finally read passages from Leaves of Grass and, as a result, despite the affection he felt for its author, wrote a letter at one point intended to end the new friendship. Before posting it, he sent a copy to Mary who entreated him not to wound their friend in this way. To bolster her argument, she used the example of Ralph Waldo Emerson, who continued to honor Whitman even after he had turned away Emerson's suggestion to remove the sex poems from Leaves. She succeeded in convincing her father not to take the renunciatory step, and the letter was not sent. ${ }^{17}$

Mary's argument may have struck a deep chord in Smith, for he himself had experienced the disgrace that could be heaped, in that time, upon one who transgressed the rules of sexual propriety. Robert Pearsall Smith had not always been an executive in Whitall, Tatum \& Company, manufacturers of glass products, founded by his wife's father. At a point earlier in their marriage he had felt compelled to act upon the religious conversion he and Hannah had experienced and which caused them to forsake their positions as birthright Quakers for evangelical Christianity. Hannah acquiesced to her husband's claim that he had been called to a full-time ministry of preaching the gospel not only because she shared his religious beliefs, but because she feared crossing him would exacerbate the emotional illness he had been experiencing ever since the death in 1872 of their eighteen-year-old son, Frank. Smith's illness was an early manifestation of an inherited bipolar mental disorder that continued to plague him throughout his life and from which his son Logan also suffered.

Robert's preaching took him as far as England and Europe, where he enjoyed phenomenal success and is credited with having influenced the founding of the Keswick Evangelical Movement, which endured well into the twentieth century. Hannah and their children joined him in London, and there Hannah began her activities, as speaker and writer, in the same religious endeavors. Robert's glorious efforts came to an abrupt end, however, when he was accused of having too ardently taught some female converts the doctrine of Christ's physical union with his church. No more succinct explanation of the effect of this doctrine has been offered than that of his son Logan who claims it is based "on the 
fact, namely, that nature, in one of her grossest economies, has placed the seats of spiritual and amorous rapture so close to each other that one of them is very likely to arouse the other."18 Sent home in disgrace, his illness once more upon him, Robert returned to the glass business, and the family moved to the house in Germantown. As a result of the scandal, Robert lost his faith entirely. Whitman later described this transition by saying, "Pearsall himself, though once a missionary or something or other of that useless sort, is now agnostic" (WWC 1:172). Hannah, though no longer an orthodox believer, remained a Christian and, with the pressures of a Quaker family and community pressing upon her, maintained a strict, religious atmosphere in their home. She soon transferred her evangelistic fervor to the Woman's Christian Temperance Union and formed a strong bond with Frances Willard, who headed it. Later she continued this interest by becoming active in the British Woman's Temperance movement and serving as its vice-president in the mid-1890s. ${ }^{19}$ Hannah had already published the book that would bring her worldwide attention (when it was translated into all the major European languages as well as Chinese and Japanese), The Christian's Secret of a Happy Life, and to this she added over the years many books and tracts. Perhaps because of Robert's downfall, she developed a scholarly interest in cults and sects, especially their practices as they related to sexuality, and her book Religious Fanaticism was published after her death.

Whitman once spoke of "the scandal-women being mixed up in it" in which Robert Smith had been involved while in England. Then, additionally, he alluded to "some trouble in the [Smith] family" as a result of which, he claimed, "for some years Pearsall and Mrs. Smith had no words - no relations - with each other" (WWC 5:54). Hints of this second estrangement appear in the literature about the pair, but it remains unexplained. It is clear, however, that, from the time of their return from England, the world, for Hannah, centered on her children, Mary, Alys, and Logan. Though she instilled in them Quaker beliefs and practices, her main objective was to make them happy, an objective which seemed to her an end fully worthy of her time on earth. So successful was she in this goal that she inculcated in them, especially in Mary and Logan, the firm belief that their individual happiness was always a first consideration to which everyone and everything else had to come second. The time came in Mary's life when Hannah may have regretted such indulgence, but she never ceased to place her children, at whatever age, first in her affections and her concern.

\section{2. "Mrs. Smith has always disliked him."20}

Whitman's word-portrait drawn for Horace Traubel of Hannah Whitall Smith, with whom the poet claimed he "never hitched," while divert- 
ing, is both unfair and lacking in discernment, for in many ways she was perhaps the most interesting member of her family. Whitman saw only a narrow-minded woman whose table offered "everything but a tipple," forcing him and others of her guests (or so he claimed) to sometimes "slip out and get round the corner." "She takes her doctrine," he told Traubel, "if she don't take her whiskey, very straight: the sort of get under my feet religion which gives hell out to the crowd and saves heaven for the few." 21 But in fact Hannah had created considerable consternation when she and her husband were preaching at the Broadlands Evangelical Conference in England, precisely because she refused to accept the orthodox notion of salvation restricted to professed believers. ${ }^{22}$ Her firm belief in a uni-

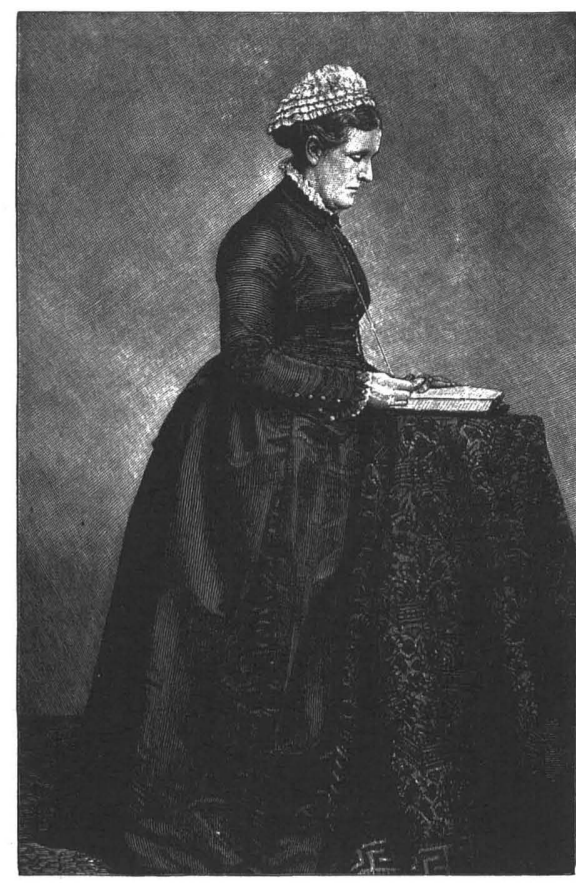

Hannah Whitall Smith, from Frances E. Willard, Woman and Temperance, 4th ed. (Hartford: Park Publishing, 1884), 193. versal hope of salvation was rooted in her faith in a loving God and in her feelings of genuine good will toward all humankind.

Whitman's impression of Hannah, that she "saves heaven for the few," was most likely the result of her disapproval of his Hicksite Quaker leanings. Whitman's parents, as well as Whitman himself, were great supporters of the Long Island Quaker leader Elias Hicks, who in 1827 created a schism within the American Quaker community by denying the orthodox belief in the divinity and atonement of Jesus Christ. Robert Pearsall Smith's mother, Rachel Pearsall, was of the influential Long Island Pearsalls who, like the Whitall Quakers, had not followed the Hicksites. In his account of his Quaker upbringing Logan Smith tells of the two meeting houses, two burial places, and two orders of preachers that represented the diverse bands. Hannah Smith's disapproval of the Hicksites, which no doubt fed Whitman's description of her, comes through to us in her son's words: "I remember climbing the wall that surrounded one of the Hicksite meeting-houses, and gazing on those precincts with all the horror of one who gazes into Hell. Never since have I looked upon any object with such feelings of abomination." 23

Hannah's insistence on the universal hope of salvation only intensified her belief in the imperative to evangelize, an enterprise that Whit- 
man contemptuously dismissed as "the 'Come-to-Jesus!' business" (WWC 5:53). Where Hannah Smith saw a sinner in need of reformation, Whitman saw a victim of societal forces, and there was no compromise between them. Perhaps they could simply have agreed to disagree except for the occasion Whitman described to Horace Traubel, when he deliberately antagonized Hannah in the matter of her beliefs before a roomful of people in her own home ( $W W C$ 5:53). It was an unforgivable breach of etiquette, and Whitman was probably correct in surmising that she had never absolved him.

Such a public affront would have been intolerable to Hannah for a number of reasons, not the least of which was the way it demeaned her intellect. She had a keen mind and was painfully sensitive about her lack of formal education. Immediately after marrying she had embarked on a course of study that included Greek and mathematics, but pregnancy put an end to it and she was never able to complete her studies. It was Hannah who urged and directed her daughters toward higher education and who ascribed to her Quaker upbringing her inability to appreciate culture. Yet, even when her Quaker background forbade her to do so, she had forced herself at seventeen to enter the Academy of Fine Arts in Philadelphia to view the statues on exhibit, including a nude rendering of Hero and Leander. Later she claimed to have thought at the time that she would go straight to Hell for doing so, but she told herself, "If I must go to Hell, I must! But I will look at this statue!" 24 So when her granddaughter Carey Thomas faced resistance from her family when she wanted to study abroad, she found a friend and patron in Hannah, who not only paid for the trip but approved of Carey's ambition as one that had once been her own. Thomas returned from this trip to become dean, and later president, of the newly-founded Quaker college for women, Bryn Mawr. ${ }^{25}$ Indeed, Hannah would have benefited from the education she craved since she was highly intelligent and, in different circumstances, may have proven herself in fields other than religion, where she did attain an acclaim that lasted her lifetime.

When they were in England as evangelists, the Smiths were not preaching to the "down and outs" of society. Through the wealthy English Quakers, they were invited to the homes of the aristocracy-the Duchess of Sutherland, Lord Henry and Lady Isabella Somerset, and the Honorable William Cowper Temple, later Baron Mount Temple, who was a Christian Socialist, noted philantropist, and the natural son of Lord Palmerston, Queen Victoria's Prime Minister. Temple's wife, Lady Georgina Mount Temple, and Hannah Smith became friends for life, and Mary introduced Lady Mount Temple to Leaves of Grass (WWC 1:94). After the Smith family had returned to London permanently, Lady Mount Temple sent Whitman a wool and silk vest. The gift caused him considerable annoyance because he had to pay a tariff to retrieve it from the shipper, which provided him a chance to expound on one of 
his pet peeves: "This whole tariff business is an insult to our good sense," he complained to Traubel, "besides being a palpable impertinence and invasion" $(W W C$ 1:94).

In the company of people such as Lady Mount Temple, Hannah Smith found the comforts and amenities of upper-class English life so enjoyable that she once declared that, had she been born in England, she would like to have been born an aristocrat. When they later established themselves permanently in that country the Smiths became part of a cultural movement of Americans abroad who similarly enjoyed life among the English gentry, including Henry James, John Singer Sargent, James McNeill Whistler, and Harold Frederic. At their country home in Surrey they entertained, largely at Mary's invitation, such people as George Bernard Shaw, the Socialists Beatrice and Sidney Webb, author Israel Zangwill, philosopher George Santayana, William James, Bernhard (later Bernard) Berenson, whom Mary eventually married, and Bertrand Russell who became Alys Smith's husband. ${ }^{26}$ In just two generations the Smith family came to embrace secular aesthetics-for Mary, a religion of art, and for Logan, of literary style. Only Hannah remained constant in her faith and probably constant as well, as Bucke surmised, in her feelings of dislike for Whitman.

\section{3. "He [Robert Pearsall Smith] never cared for Walt."}

The final removal of the family to England had nothing to do with Robert Smith's position in the Whitall business. Though for a number of years he had continued to reap the benefits of the very profitable firm, by the time Whitman knew him Robert played almost no role in its administration. Still, he was always princely in his behavior toward Whitman, especially in the matter of the poet's 1887 Lincoln lecture at Madison-Square Theatre in New York, Whitman's most successful venture into lecturing. It was Smith who paid for the reception at the Westminster Hotel, which, Whitman insisted to Horace Traubel, he himself had protested but which Smith nevertheless arranged "with a certain grace and generosity that touched me" (WWC 1:172). Logan Pearsall Smith was present at the reception and wrote to Mary that "all the literary swells were there and everyone was enthusiastic about [Whitman] and his lecture. I am so glad he had this bit of hero worship at the end of his life." 28

The glass company, though even more profitable after the invention of furnaces that increased productivity, held small attraction for the Smiths. Robert felt that he was never treated as an equal by his wife's relatives who managed it, and Logan, who was sent to work in the firm's New York office after completing college, escaped after only a year to Europe with his mother's blessings and an annuity bought with a sum settled on him by his father. Logan had wisely chosen the lump 
sum settlement rather than an allowance, for he feared his father's recklessness with money, especially in the periodic euphoric states brought on by his illness. In one such episode Robert bought a large number of shares-\$50,000 worth-in the Sierra Grande Mines of New Mexico, two hundred of which he generously gave to Whitman in the expectation that they would yield a monthly income of fifty dollars. Whitman received nine small dividends before the shares all became worthless. ${ }^{29}$ Smith also offered Whitman a burial plot in the Laurel Hill Cemetery in Philadelphia, which his father John Jay Smith had founded, but Whitman seemed not to be interested in the offer ( $W W C$ 6:210). There had also been some vague plans, in 1884, for an edition of Leaves of Grass underwritten by Hannah and Robert. The funding would have derived from Hannah's share of Whitall, Tatum profits, however, and, although she fulfilled her wifely duty in turning all of these over to her husband, she refused to sanction this undertaking (Corr. 3:366 n.24). The Smith family continued to live comfortably for many years on Hannah's income, and there is evidence that at least once (and probably more often) Robert Smith sent gifts of money to Whitman from England (WWC 6:157).

Whitman's friendship with Robert Pearsall Smith was rare in the poet's experience of men, for Smith was neither a laborer nor a literary man. Whitman knew that Smith felt no enthusiasm for the great "cause" of Whitman's life - believed, in fact, that Smith did not understand Leaves of Grass - but he treasured Smith's catholicity, his acceptance of all things and all people. When Henry George visited England in 1889 Smith took him for a carriage ride, and they freely exchanged views on economics and trade. Whitman saw in Smith's acceptance of the radical George proof of his friend's "drift toward [such] discredited fellows" and his tendency toward a kind of recklessness Whitman called "the Western freedom." (WWC 5:52).

Smith's genuine kindness and generosity were great attractions for Whitman, of course, but there was also an awareness on Whitman's part of his friend's capacity for enjoying the material things in life without losing sight of the spiritual. Whitman always admired men who had been successful in business (a feeling born, perhaps, of the consciousness of his father's failure), but often the admiration was tempered by the belief that they had sacrificed much of their inner being in the pursuit of material success. He seems too to have been able to relate to Smith's varying moods, enjoying with him the exhilaration of fast driving and the pleasure of watching young lovers, but also extending himself in thoughtful letters. Smith once wrote to him that "my old enemy 'melancholia' spreads its vampire wings still over my life and will I presume go with me to the end." 30 Whitman expressed an understanding of the nature of inherited dispositions by gently pointing out how lonesome he had been during a recent illness and that had he not been born 
"with a happy-tending natural disposition (I inherit it from my mother) the last few weeks - yes the last ten years-would have been unmitigated darkness and heaviness to me" (Corr. 3:365-366). The last words of this sentiment convey well the feelings that overwhelmed Smith in his periods of depression, feelings which Whitman validates in his friend even while personally disowning them.

Bucke's report to Whitman concerning Robert Pearsall Smith was that Smith believed Bucke had "a loose joint somewhere" for admiring Whitman as he did, but this must be taken with some suspicion. Even granting that Bucke was right in his judgment, that Smith "did not understand the old man-never had understood him," the evidence of the years of friendship is that, despite this lack of understanding, Smith cared very much for Whitman, and that the alteration in feeling must have been occasioned by something, or someone, so important in his life as to make the defection possible-someone such as Mary.

\section{4. "Again, there is Costelloe . . he fears Walt."}

It was Mary, Whitman's "bright particular star," as he once called her, who precipitated the family's removal to England. Just as it had been she who steered the family toward Whitman, it was she who impulsively and often willfully directed the flow of its life. Mary was a tall young woman, strikingly lovely, with the intellect and wit to make the most of her physical attributes. It says a great deal about Whitman's feelings for Mary to know that he compared her to two women he held in the highest esteem, Frances Wright and Anne Gilchrist (WWC 2:205; 4:189). Mary laughed easily and often, and she attracted men in what her brother termed "a prenuptial flight . . . of admirers, suitors, beaux, and wouldbe lovers." 32 Mary would continue to have this effect on men for many years. Perhaps because she had been raised in an atmosphere of personal indulgence, Mary would not resist the temptations men presented when the moth and flame attraction was no longer prenuptial.

Mary Whitall Smith was attending classes at Harvard when a young Anglo-Irish barrister came to lecture and changed the course of her life. He was Benjamin Francis Conn Costelloe, and he had come from London, England, to attend the fifty-fourth annual convention of the British Association for the Advancement of Science held in Montreal in August 1884. Frank, as he was familiarly known, was ten years older than Mary and some inches shorter than she, but darkly handsome and a graduate of Balliol College, Oxford. He was also a pious Roman Catholic with Christian Socialist ideals and political ambitions that included an ardent advocacy of Home Rule for Ireland. Mary invited him and his English companions to Germantown and, as she was wont to do, took them to meet Walt Whitman.

By this time Walt was living in his Mickle Street home. Mary and 
her mother and sister had made him a combined birthday and housewarming gift of bed linens and pillows which he had gratefully acknowledged (Corr. 3:370). Always pleased to see Mary, Walt had no doubt also become accustomed to the visits she engineered for others. In addition to her father, brother, and sister, she brought her friends. One of these was Agnes Orbison, then a student at Bryn Mawr College, who was an aunt to James Joyce's friend Sylvia Beach. According to Beach, "On taking leave of the poet, Agnes Orbison asked him if she might have some of the notes and snips of paper that littered the floor, and he said: 'certainly, dear child." "The notes and "snips" later came into Beach's possession and were auctioned in $1922 .{ }^{33}$

For the perhaps apocryphal story of another of Mary's accompanied visits we are dependent upon the somewhat questionable memory of Logan Pearsall Smith. According to Logan, Mary was on her way by ferry to visit Walt on February 3, 1885, when she noticed a well-dressed gentleman on board. Surmising his destination was the same as hers, she offered to show him the way. The object of her kindness was Edmund Gosse, the English poet and literary critic, on his way to visit Whitman. When they arrived at the house there was no response to their repeated knockings, but Mary felt certain Whitman was in his room upstairs. She prevailed upon the Englishman to let her boost him up to a window which, once opened, would allow him to enter and unlock the door for her. Though disconcerted by the proposal, Gosse is supposed to have agreed and subsequently enjoyed a fine visit with Whitman. Logan Smith admits that years later when he brought his sister and Gosse together for lunch, Gosse recalled meeting her at the Camden house but "strenously denied" having entered it in so unorthodox a manner. ${ }^{34}$

For Frank Costelloe's visit we have ample verification from both Whitman and Mary. ${ }^{35}$ A letter from Mary to Walt, written in November 1884, refers to the visit and tells him that Costelloe read "the little book you gave him" to passengers on the steamer back to England. His audience responded warmly to the poetry, Mary says, adding, "You certainly do blow 'grit' into people" (MB 28). Mary herself was far from lacking grit. A steady stream of letters between her and Frank led to a secret engagement which, when her family learned of it, caused great consternation mainly because of Costelloe's Catholicism. To learn more of him, the Smiths arranged to visit London, and on June 20, 1885, Mary made a farewell call at Mickle Street.

Their parting must have been difficult for both; Mary meant enough to Whitman to cause him to break his longstanding rule against such practices and write a letter of introduction to Alfred Tennyson for her and Alys. She and Alys and their father had lunch with the great man at his country estate in July, and Mary found him "exceedingly interesting in conversation" (MB 29). Her excitement at the visit can be surmised from Whitman's August 1885 letter to her which begins, "Your third 
letter about the Tennyson visit arrived today. . . " (Corr. 3:401). Whitman and Traubel remembered the three letters, filled with details of the visit, when Dr. Bucke, reporting expansively on his own reception by Tennyson, claimed that "the Smiths were not admitted-never got to see him." Both his hearers protested that they had received just the opposite impression, to which Bucke could only retort, "That's not the way they put it now" (WWC 8:470). Small wonder that Whitman was confused by such conflicting accounts.

The entire Smith family had gone off to London to see if this Irish Catholic was worthy of their Mary, but what they thought would have had little effect. Mary was caught up in a love that was heavily tinged with hero worship, and she was convinced that joining her life with Frank's would ennoble her and bring purpose and direction to her existence. In a letter written home after her marriage, she exulted, "from the moment when he told me that to his mind the foundations of the world were the four corner stones of God, Duty, Free-Will and Immortality, and (as was his wont) he was prepared to prove them to me, I knew he could help me" (MB 37). One can detect in just this one statement some of the problems that would arise once Mary tired of the pressing weight of those cornerstones, and of her husband's "wont" to "prove" to her the correctness of his position on any matter.

Hannah had a particularly difficult time accepting her daughter's engagement: while she could not help but admire her future son-in-law, he was clearly a rival not only for Mary's affection but for her spirit. Once married to him, Mary's letters to her parents were full of "Frank says," "Frank thinks," "Frank believes," while Mary's own thoughts and beliefs faded into oblivion. To her sister Alys she wrote: "He is so much better than I. He does what he ought and doesn't go about following out his own whims and desires regardless of the moral law. And that regardlessness has been the evil of my training" (MB 32). It is not difficult to imagine that such a high-minded, morally obligated individual would find it impossible to sanction Mary's motto, taken from Whitman, by which she ordained herself "loos'd of all limits."

They were married on September 3, 1885, and had their wedding reception in the dining hall of Oxford's Balliol College. Their honeymoon was spent traveling through Scotland on a Home Rule for Ireland campaign. It was the beginning of a life completely dominated by Frank's political and social ambitions. Logan Smith tells us that Benjamin Jowett, the noted philospher and Costelloe's mentor at Balliol, even cautioned his student that while it was "most important in this world to be pushing, it is fatal to seem so." ${ }^{36}$ Frank failed to heed this wisdom, however, in his headlong dash for success as a barrister, a politician, and as a bringer of what Logan called "the Kingdom of God in London." The young Costelloes held as their heroes Jowett, William Gladstone, leader of English Liberalism, and Arnold Toynbee, the social reformer and 
nephew of the historian Arnold Joseph Toynbee. To Mary's great delight she found the Oxford followers of Toynbee, a tutor at Balliol who died in 1883 at the age of thirty-one, to be devotees of Walt Whitman. Young Toynbee is believed to have exhausted his health in well-doing among the poor of London, and Toynbee Hall, London's first settlement house (opened in Whitechapel in June of 1885), was named in his honor. Here young liberals like the Costelloes, speaking reverently of Whitman as "Master," labored mightily for the benefit of the city's downtrodden (Corr. 3:396 n.45). Though the Costelloes did not consider themselves Socialists, they were not far removed from the principles of others among Frank's friends who were members of the Fabian Society, an outgrowth of an earlier, less secular, group called the Fellowship of the New Life. In this regard Mary once wrote Whitman that she and Frank were "working out our idea of the ideal State, as a sort of supplement and corrective to Socialism" (MB 36).

Mary sent Whitman an account of the opening of Toynbee Hall which brought from him a short descant on the subject of philantrophy and Christian socialism in a world dominated by the interests of capitalism:

I think much of all genuine efforts of the human emotions, the soul and bodily and intellectual powers, to exploit themselves for humanity's good-the efforts in themselves, I mean (sometimes I am not sure but they are the main matter)-without stopping to calculate whether the investment is tip-top in a business or statistical point of view. These libations, ecstatic life-pourings as it were of precious wine or rose-water on vast desert sands or great polluted river - taking chances for returns or no returns - what were they (or are they) but the theory and practice of the beautiful God Christ? or all divine personality? (Corr. 3:397)

It is doubtful that Whitman considered himself, at this point in his life, as an object of Toynbee-style philanthropy, though in 1876 he had stirred a considerable tempest among his English followers by publicizing his own supposed neglect and dire need. But Mary had a letter from her brother written in November 1886 in which Logan described a visit to Whitman. The poet was recovering from an illness and, despite his protestations to the contrary, Logan's feelings were that Whitman "was old, sick and alone." 37 Mary's work in what she called "the slums" of London (which she confessed to her mother bored her so that "I think I shall not do very much of that kind of work in the future") may have led her to think of her aging friend in his less than prosperous neighborhood. To her family in Pennsylvania she wrote,

... I wrote a long letter to dear W.W., whom I hate to think of as suffering and lonely. $\mathrm{O}$ do all you can for him in the years that are left to him to live, for whatever you may think of his poetry, he is a great genius and a genuinely good and beautiful old man, and he deserves far more than the world has given him. (MB 34) 
She must have spoken in the same way to one of Frank's friends who was an editor of the Pall Mall Gazette and an admirer of Leaves of Grass. The Gazette ran a story inviting readers to contribute to a fund for the American poet, and at the end of 1886 a sum of eighty pounds was sent off to Camden. Protests in some American newspapers forced the $G a-$ zette to retract statements it had made regarding Whitman's poverty, and on December 23, 1886, it published a piece by Mary titled "Walt Whitman at Camden, By One Who Has Been There." In it she gave a lovely picture of Walt's life in Camden and quoted from his recent letters to her, then ended with these comforting words: "Walt Whitman, then, is not either miserable or in want, but none know better than those who know him best how happy it will make him to find that a spontaneous movement of English sympathy is sending him a Christmas gift."

Mary's letters to Whitman were long and full of news of London and its affairs; he thought so highly of them that he sent them on a "round-robin" to his closest friends-William O'Connor, Dr. Richard Maurice Bucke, John Burroughs, and William Sloane Kennedy. He eagerly awaited word of a visit Mary was to make to Anne Gilchrist, who in her final letter to the poet expressed an equal eagerness for the meeting. Because of Mrs. Gilchrist's illness and death late in 1885, the meeting may not have occurred, but Mary did meet Herbert Gilchrist. She began sitting for a portrait he was to execute, though it is uncertain if it was ever finished (WWC 4:189 n.6). On a late summer visit to Switzerland in 1887 she and her father called on John Addington Symonds in Davos. Symonds gave Robert a copy of his published response to Swinburne's Fortnightly Review attack on Whitman, which Robert sent on to Whitman (Corr. 4:120). No doubt Symonds found Mary as entrancing as did another of Whitman's London friends, Ernest Rhys. Rhys and his sister lived very near the Costelloes in the Westminster region of London, and Rhys wrote to Whitman how favorably impressed he was by her, claiming "She is one of the five or six noblest women I have come across; I say this quite deliberately." Her husband he found to be "a very genuine and capable fellow" but of "too hard an intellectuality." (Corr. 4:99 note 80).

Though Whitman took little interest in Mary's accounts of the London talks she gave on women's suffrage, he found her so generally admirable in all her activities that he told Horace Traubel she was "quite a great woman in her way-a true woman of the new aggressive type: though going so devotedly, whole-heartedly into public work she does so abrogating nothing of her ... womanliness" (WWC 3:357; 4:188). The "great woman," however, was exhausting herself trying to fulfill all the responsibilities she had arranged on Frank's behalf. Her family had returned to America and she missed the loving support they had always 
provided. To Logan she wrote of Frank's multitudinous obligations and to her mother of her own endless rounds of giving speeches, doing good deeds, entertaining, and helping Frank in whatever ways she could. She continued to maintain this schedule even during her pregnancy (despite the fact that she had miscarried earlier) as well as after the birth of her first child, Rachel, in June, 1887. The first signs of Mary's inability to live by Frank Costelloe's rigid code of unending selfless activity came the year after Rachel's birth, when she wrote to her mother that she was "lazy" and did not wish to fulfill all the obligations laid upon her, "but Frank is always urging me on" (MB 39).

Hannah and Robert had followed up their 1885 stay in London with a tour of Europe the following year, while Alys pursued her studies at Bryn Mawr College and Logan studied in Germany. In the fall of 1886 Robert and Hannah returned to America only to sail for England again for the birth of Mary's baby. A year later Hannah made up her mind that the family should permanently move to London to be with Mary. Alys would continue her studies at Bryn Mawr College, and Logan would attend Oxford College. This ended Logan's association with the firm of Whitall, Tatum, because at Oxford he determined-much influenced, he later claimed, by his friendship with Walt Whitman-to become a writer.

Whitman said his final farewell to Robert Smith, who assured him there would be a room kept for him in his London home, and the family left for England on June 13, 1888. While there is no indication Hannah also bade Whitman farewell, she did write to Mary that Dr. Bucke, fearing Whitman was failing, had tried in vain to have him arrange his literary affairs. She encouraged her daughter to write the story of her acquaintance with the poet and (seemingly verifying Logan's report of Gosse's visit) to include "the time thee was there and had to get in through the window and found him so forlorn." 38

Once in London, the Smiths settled in a house just a few doors away from Mary and Frank on Grosvenor Road, and Hannah, revelling in the role of grandmother and with her favorite child, Mary, again near at hand, was happy. Her other daughter, Alys, wrote comforting letters from Bryn Mawr College to assure her mother that she would never marry.

\section{5. "Alys never cared anything for Walt."}

While she was at Bryn Mawr, Alys Pearsall Smith (1867-1951) took it upon herself to look in on Whitman now and then and to write to him between visits. Alys wrote from college, from her sister's home in London, and-expressing great sadness at leaving him-from the mid-Atlantic as she sailed to England to make it her permanent home. Her tone was never anything less than loving and respectful, and her con- 
cern for his health and well-being was evident. Whitman found her not only beautiful and a source of joy, but also the "most Greek" of "any girl in America-Greek from top to toe," though he offered no explanation of this beyond saying that a friend had once described Leaves of Grass in those words (WWC 6:157). Alys seemed to him an extremely perceptive reader of Leaves, so much so that when he was debating the inclusion of "A Backward Glance" in Leaves of Grass and Alys suggested it become an epilogue, he "gave the notion good attention" (WWC $8: 422$ ). He was keenly disappointed when she wrote to say she would not attend his birthday celebration in 1890 . The pressure of preparing for exams was her given reason, but Whitman's disappointment was so great that his first reaction was to suspect her of a change of heart toward him, and he briefly suggested to Traubel that they cancel the celebration ( $W W C$ 6:424).

Alys did not defect, though she did lose touch with Whitman in succeeding years. In the summer of 1889 , which she spent with her family in England, she met the shy, seventeen-year-old Bertrand Russell (1872-1970), whose impression of her was that she was "very beautiful ... and more emancipated than any young woman I had known, since she was at college and had crossed the Atlantic alone. . . . I fell in love with her at first sight." 40 At that time Alys, under Frank Costolloe's influence, had involved herself in philanthropic work and had little time for Russell. It was not until 1893, when she was living permanently in London, that Alys found herself returning Bertrand's affection. They married in December 1894. Two years later, when they came to America to visit Alys's relatives, Russell claimed that the first place his wife took him was to see Whitman's house on Mickle Street. ${ }^{41}$ The couple was quite happy for a number of years before Bertie, as he was called, fell passionately in love with Lady Ottoline Morrell, and in 1911 there was a separation, which ended in divorce in $1920 .^{42}$

Russell shared Alys's love of Whitman and once depended upon the influence of Leaves to help Alys overcome her aversion to sex and childbearing so that they might marry. In the summer of 1893 Russell wrote an essay for Alys, "Die Elie" ("Marriage"), in which he argued the benefits to the human race of children born to superior individuals. At the head of the essay stands Whitman's "Unfolded Out of the Folds," which extols the role of "the superbest woman" as the bearer of superb children. In his diary Russell wrote of his frustrations at Alys's delays adding, "But Walt and work will I hope help me through." 43

While he was at Cambridge, Russell was a member of The Cambridge Conversazione Society, better known as The Apostles. One of his papers read to this group in 1894 was on the subject of the passions and their governance. In it Russell refers to "the Whitmaniacs," who feel no shame at those passions of "the sane and healthy man or woman," and quotes, incorrectly, from "A Woman Waits for Me" and "Song of 
the Open Road."44 Perhaps the inaccuracies in quotations were because he lacked a copy of Leaves or was dependent upon Alys's copy. A year before her death Alys sent Russell a copy of the 1882 Leaves of Grass, which was inscribed to her by Whitman and from which most of the Children of Adam poems had been cut out. To Whitman's inscription she added "For Bertie from Alys, 1894-1950, From a former ArchPrig to the other former Arch-Prig!"45 The term "Arch-Prigs" will be better understood when considered in connection with her brother Logan.

6. "Why there's Logan. He's quite warm for Walt. But Smith, the old man, don't like it-sort of pulls the young fellow up for it. " ${ }^{46}$

Like Alys, Logan Pearsall Smith (1865-1946) continued his relationship with Whitman by visits and letters after his parents moved to London. While at Balliol College, Oxford (he too had come under Frank Costelloe's influence), he wrote often-cheerful, respectful letters addressed "Dear Mr. Whitman." Whitman told Horace Traubel, "Logan is a good boy ... he is at Oxford-writes me faithfully-I as faithfully enjoy him."47 Before going to Oxford, when Logan was traveling in Europe in the fall of 1888, he wrote to Whitman from what Walt declared "an unpronounceable place in Wales" (Llwyorbarried House, Rhaydr). Vowing to answer to London, the poet exclaimed, "Such a name deserves to be ignored" (WWC 2:340).

The influence of his brother-in-law did not stop with the choice of college, for Logan quickly became involved in the socialism that swirled around him. Mary wrote to Whitman that Logan was busy with an attempt to reduce the excessive expenses of Oxford which made it impossible for any but wealthy men to be educated there. "As rich people have evidently no monopoly of brains," she wrote, "it is a great pity that all this splendid training is accessible only to them. Some day a Royal Commission or something like will thoroughly expose the manifold iniquities of that most delightful of all Universities - and perhaps things will be changed then." Efforts such as these may not have endeared Logan to Balliol, whose graduates were some of Britain's most outstanding establishment figures.

Frank Costelloe was not solely responsible for Logan's altruism. In his memoir, Unforgotten Years, Logan attributed his democratic principles to his reading of Whitman, and revealed some depth of emotion at Whitman's ability to demonstrate affection for others, claiming he was "one of those rare spirits who really love the human race." 48 Later Smith would abandon his democratic, and socialist, principles for a life of cultural elitism in which the delicacy of a phrase was the dominant charm of life, but in his youth few things affected him as did Leaves of Grass. He recalled sitting with Whitman on the porch of the house in 
Germantown in 1884 and asking about the inspiration for "With HuskyHaughty Lips, O Sea!," just recently published. Whitman told him of boyhood days on Long Island when he would try to understand the whisperings of the voice that seemed to speak to him out of the sea's roaring. Smith claimed the poet explained his "poetic method" as consisting of a receptivity to experience and "a patient effort to grasp its deepest meaning and to embody that meaning in significant words." 49

Years later, when Smith had found his proper literary metier-the development of a single thought into the polished elegance that became his hallmark - he gave evidence of having taken Whitman's words to heart. Logan considered himself a lexicographer as well as a stylist, and he was interested in the meaning and histories of words. In his study of the English language, Words and Idioms (1925) - where he twice refers to Whitman as a true, original genius - he devotes the first chapter to "English Sea-Terms." Here he examines the origins and meanings of the various words connected to England's sea-going history and is especially interested in the foreign words embedded within. These words, Smith says, come to our English vocabulary "like jetsam washed from afar." Perhaps remembering Whitman, he adds, "Words are like seashells" and like the sea itself "are full of old echoes." 50

While Logan was still at Oxford he had written to Whitman of his hopes of becoming a novelist. He wanted to write about Philadelphia's Quakers, whose traditions he thought "much better material than the New England Hawthorne made so much of." ${ }^{51}$ His first published volume, The Youth of Parnassus (1895), was a collection of short stories set in Paris, but fiction writing did not suit him. Later works, totaling about twenty titles, included collections of aphorisms, his own as well as those of others, the first of which he referred to as Trivia (1903) and the last, All Trivia (1933). Gore Vidal, a latter-day admirer, calls these sometimes precious but always stylish maxims l'espirit d'escalier, "the wit of the staircase," those witty things not said at a party but which occur to one on the staircase when leaving. ${ }^{52}$ Smith's Life and Letters of Sir Henry Wotton (1907) remains the definitive biography, and his interest in seventeenth-century prose led him to write scholarly articles on Jeremy Taylor and John Donne.

When Smith recalled his first experience of Leaves of Grass, he spoke of it as a "revelation" and claimed such books "should above all reveal us to ourselves, should hold up a looking-glass before our eyes in which we see our own faces." 53 Whether it was Whitman's poetry that brought him to an awareness and an understanding of his own homosexuality is not clear, but Smith does offer this:

Much that was suppressed in the young people of my generation found a frank avowal in Leaves of Grass; feelings and affections for each other, which we had been ashamed of, thoughts which we had hidden as unutterable, we found printed in its pages, discov- 
ering that they were not, as we had believed, the thoughts and feelings of young, guilty, half-crazy goblins, but portions of the Kingdom of Truth and the sane experience of mankind. ${ }^{54}$

Bertrand Russell claimed that in the first years of their acquaintance Logan gave him much moral advice, and that in 1889 Logan was, in matters of sexual morality, "very ascetic, in fact almost Manichaean," and hoped to persuade other agnostic free-thinkers like himself "to preserve a high standard of personal discipline and self-denial." 55 To this end he created a humorous group, the Order of Prigs, into which he initiated Russell in 1891 with a series of rules which, though they followed a general code of self-denial, made no direct reference to sex. ${ }^{56}$ The rules speak of "The Arch-Prig" as having power over the Order, and it is to this imaginary (unless it is intended to be Logan himself) personage Alys alluded in presenting Russell with her copy of Leaves of Grass.

Aside from those with family members, Logan had only two relationships in his life that were of real significance to him. One, the longest and most meaningful, was with Philip Morrell and began when they were fellow students at Balliol. Logan turned against him, however, when Morrell married Lady Ottoline Cavendish Bentinck, claiming the marriage was born solely of Philip's ambition. Later, he found that he liked Lady Ottoline sufficiently to allow him to visit their home in order to see her, not Philip. But even this arrangement was abandoned when Logan's brother-in-law Bertie began his affair with Ottoline. The other relationship, begun late in his life, lasted seventeen years. It was with Robert Gathorne-Hardy, a poet and novelist, who later wrote Recollections of Logan Pearsall Smith (1949), in which the author recounts Smith's rejection of him in the closing days of his life when madness had overtaken him.

It is impossible to know if the Smith family was aware of Logan's homosexuality or if his parents harbored any suspicions about Whitman (as might be inferred from Dr. Bucke's remark) that might have contributed to their renunciation of the poet. Logan's biographers speak of a long succession of young male secretaries and of his open rage at Philip Morrell's desertion. One recent chronicler of Bostonian social circles of the 1880 s argues, though without verification, that it was the break-up of an affair between Logan and Joseph Gardner, Jr., the adopted son (and nephew) of Isabella and Jack Gardner, the Boston millionaire, that precipitated young Gardner's suicide in $1886 .{ }^{57}$ This tragic event occurred in the same year that Logan went to study in Germany, and, since the Smiths were traveling in Europe at the time, it may not have been known to them. Robert Smith's letters to Whitman from London give no indication of Bucke's claim that the father was unhappy with his son's admiration for Whitman. Smith praises his son's industry at Ox- 
ford and his plans for a future as a writer, and he is free and full in communicating news of Logan to Whitman.

Certainly the family could not plead ignorance to other instances of homosexuality among their acquaintances. Just about everyone was aware of the scandal that engulfed Hannah's dear friend Lady Isabella Somerset, the Duchess of Beaufort, when the Duke was found to be carrying on an affair with a footman. Lady Somerset took her husband to court and, though she won a divorce, she was no longer welcomed by society. Instead she joined Hannah in working with the British Women's Temperance Association and came with Hannah on a visit to the United States, where she was introduced to the wife of President Harrison. ${ }^{58}$ Admittedly, Lady Somerset's tribulations were far removed from Logan's literary circles, but Robert Gathorne-Hardy was a close friend of Alys, who lived in her brother's home for a number of years prior to his death. Before that, Hannah Whitall Smith had lived with Logan from the time of Robert's death to her own death. Such proximity would have been revealing, but Gathorne-Hardy claims Hannah "neither questioned, nor interfered with his [Smith's] ways of living." 59 Nor is Mary likely to have done so, since she was so fond of Oscar Wilde that, at his sentencing to two years in prison, she wrote in her diary: "And when you think how common the vice is, it is sickening to think that the punishment has fallen on the most brilliant of them all." 60

In sum, there is no evidence (other than a possible veiled implication in Bucke's statement) that any member of the family feared Whitman's influence on Logan as an encouragement of his homosexuality. Since it was generally the case at the time that objections to Whitman were based on the blatant sexuality of the Children of Adam poems rather than the Calamus section, it may be assumed that, if Bucke was correct, Robert Pearsall Smith's "pulling up" of Logan's warmth for Walt was predicated on more generalized moral terms.

\section{7. "There's another cause with Mrs. Costelloe, greater than any other."}

With the Smith family settled in on Grosvenor Road, just four doors away from the Costelloe family, and with Mary expecting her second child, all seemed to be well. The child, another girl, was born in March of 1889 and named Catherine but called Karin. These two sisters, Rachel and Karin, would make the kinds of illustrious marriages their mother and aunt had made, and they would also distinguish themselves in other ways. Rachel (known as Ray) married Oliver Strachey, brother of Lytton Strachey, and Karin married Adrian Stephen, Virginia Woolf's brother. Ray also followed in her grandmother Smith's advocacy of women's rights, while Karin became one of England's earliest psychoanalysts.

Mary still wrote to Whitman with some regularity, though her days and nights were so full of activity that it was difficult for her to stay 
current. Earlier, in 1887, she had found time to discuss literature in her letters, as when she took up the subject of Tennyson. She found the English poet "great in spots, and the cracks filled in with inferior stuff." Having referred to "Locksley Hall Sixty Years After" as an "outburst of cynical pessimism," she defended her position:

Perhaps thee will think this the hasty and impulsive judgment of youth. I will begin to reconsider it when I find thee issuing a latest edition of Leaves of Grass with all the optimism and faith and kindliness left out. I should have been glad to die before I had left such a message as my last utterance, the final outcome of a long life of experience and thought. ${ }^{62}$

Some slight abeyance of work had come after Frank lost his bid for Parliament, in 1886, as one of Gladstone's Home Rule ministers. At that time Gladstone was readying a big push for Liberalism with the introduction of the first Home Rule for Ireland bill, which failed in the House of Commons. In the fall of 1888 Frank was elected to the London County Council, and with his law practice and other work in the causes of Liberalism, he had little time for Mary-except as his partner in political and social endeavors. By the end of 1889 Mary was writing bitterly in her diary of how marriage took "everything from the woman," and how a husband, even one as unselfish as Frank, "absorbs the whole woman's life" and leaves her no room for individual development. ${ }^{63}$ The first hint of this discontent reached Whitman via a visit from Alys, when she returned for her final year at Bryn Mawr in the fall of 1889 . Whitman wrote to Dr. Bucke that although Mary was "not ill," she was still not as "stout \& well \& hearty" as the rest of the family: "I guess 'society' (a great humbug) is a bad strain on her, \& the responsibility of household \& two little children-\& Mary is not a rugged girl" (Corr. 4:385).

Not long after this, Whitman had a letter from Robert Smith telling of Mary's "nervous break-down-not suffering much but compelled to great quiet" (Corr. 4:390 n.24). Then came a letter from Mary with news that she was going with her mother to the Pyrenees for her health. Her description of her ailment corresponds with that of someone suffering clinical depression and suggests she was showing signs of the inherited affliction that was rampant in her family. Whitman sent this letter on to Bucke, expressing his fear that the planned trip would not cure but rather would exacerbate her condition (Corr. 4:394, 395). Dr. Bucke had visited the Costelloes in their London home in the spring of 1886 and evidently agreed that Mary's new life was too enervating. On learning of the current breakdown, he told Whitman that he was sorry for Mary, "but the fact is the life she went in for (an attempt to carry all London on her back) was simply suicidal" (Corr. 4:394 n.34). The word no doubt struck fear in Whitman's heart, for it had been just the year 
before he met Mary that Beatrice Gilchrist, daughter of his dear friend Anne Gilchrist, had committed suicide. Early in January 1890 Alys wrote the reassuring news (duly sent on to Bucke) that the source of Mary's trouble had been her eyes, and that she was much better since wearing spectacles (Corr. 4:403).

Indeed, for a brief time this eye condition was accepted in Grosvenor Road as the cause of Mary's breakdown, but, while Hannah Smith comforted herself with that notion, Frank and Mary knew better. Mary believed a large part of the problem was her inability to accept Frank's religion as her own (for one thing, she refused to believe in hell), and she was probably correct, for Frank set great store by his ability to convince others of his own beliefs and principles. He had published a proselytizing pamphlet, The Church Catholic, in 1889, but it had little effect on his wife. Mary sent Whitman a copy, which he gave to Traubel, advising him not to return it since it was of "no importance whatever" to him and he had no intention of reading it (WWC 4:77-78). On another occasion he explained the relationship between the Costelloes, relative to religion, as possible because of Mary's being "a thorough Leaves-of-Grass-ian - has no bigotries, no exclusions" and because of Frank's liberal position on women's equal rights (WWC 4:491). It was an optimistic, though unrealistic, assumption.

In February 1890 Whitman wrote lovingly to Mary using the Quaker style of address, which the Smiths (except for Robert) always used. He cautioned her, "Don't invest thyself too heavily in those reforms or women movements or any other movements over there-attend to thyself and take it easy"(Corr. 5:26). While not heeding this advice entirely, she did spend a good deal of time that summer at Costelloe Cottage near Friday's Hill, the country house her parents had taken at Haslemere, in Surrey. The estate was quite near that of Tennyson, a mark of distinction that much impressed Whitman (WWC 5:479). The company at Friday's Hill was, as always, intellectually stimulating, and a renewed Mary entered fully into lengthy conversations and discussions with the many guests, most of whom were there at her invitation. Among these was a young man she and Frank once had entertained at dinner and whom she wanted to know better, Bernhard Berenson.

Bernhard (during World War I he dropped the " $h$ ") Berenson was not yet the great art critic he would later become. He was just a bright, young, dark-eyed Bostonian Jew of Lithuanian origin. He had been at Harvard when Mary and Logan were there, but they had not met until he was at Oxford and Mary was encouraged to make his acquaintance because he was so promising. It was Berenson's enormous promise in the field of art that had led Isabella Stewart Gardner, wife of the Boston millionaire Jack Gardiner, to finance his travels and studies in England and on the continent. Berenson later repaid the debt by purchasing for 
her some of the finest examples of Italian art, which became the foundation of her famed collection. When he appeared at Friday's Hill for the first time, in the spring of 1890 , he had already decided on Italy as the scene of his life's work and on Italian Renaissance art as the object of what proved his undying devotion. His knowledge of his chosen field was so great that Hannah Smith declared, "[he] seems to know everything about every picture that has ever been painted." ${ }^{4}$ Mary's reaction was similar but far more romantic: "When this beautiful and mysterious youth appeared ... I f felt like a dry sponge that was put in water." His total dedication to beauty in art and poetry made her believe "that those were the real values for me, however wicked and self-indulgent they might be." 65

Mary spent a good deal of time that summer with Berenson, as he was known to everyone, and in the fall he accompanied her and Frank on a trip to France, after which he returned to Italy and they to London. Once again she took up political responsibilities, giving speeches in support of one of her husband's favorite causes, Irish Home Rule. It was particularly important to keep this issue alive just at that time in the wake of what Logan Smith referred to, in a letter to Whitman, as "the Parnell crisis," the Irish nationalist's having been named as correspondent in a divorce case. Mary wrote of it to Whitman as "Parnell's incredible meanness" in dealing "the death blow to Home Rule in his generation," while Logan rather flippantly commented, "certainly the Irish make politics dramatic!"

In February 1891, all of these concerns were swept aside when Berenson came to London and, judging by Mary's letters, became her lover $(M B 45)$. They appear to have kept their affair secret, but Frank was not entirely deceived and was only temporarily mollified by his apparent success in converting Berenson to Catholicism. (Berenson's conversion was motivated by his desire to better be able to enter into the feelings that produced the religious paintings he worshiped.) In the summer, Berenson returned to Italy, and Mary told her husband she wanted to join him there to study art. It was now clear to Frank what was happening, but he agreed, and, in the interest of propriety, escorted her as far as Paris. Mary went on to join Berenson in Antwerp, beginning a life of passionate devotion to the religion of art and to its high priest, Berenson. Her journey toward a new life began in August 1891, just one month after Dr. Bucke's arrival in London.

No wonder Bucke was bewildered by the cool reception he received at Grosvenor Road! He had expected to stay with the Costelloes as he had in 1886, but no offer was forthcoming. When he was entertained at dinner the atmosphere was decidedly strained, with no mention, other than his, of Whitman. He stayed instead with his friend Buxton Forman, who insisted that it was the enmity of Hannah Smith and Frank Costelloe toward Walt that lay at the bottom of the near rudeness Bucke had 
experienced. There was a belated invitation for a Sunday visit at Haselmere, and, in the carriage ride from London with Mary, Bucke introduced Whitman's name into the conversation but Mary failed to respond. Nor did Robert Smith inquire after or speak of their mutual friend. Only Hannah, in her characteristic fashion, was outspoken enough to say something "significant" about Walt, though in his letter Bucke did not elaborate on this.

It is not difficult to conjecture the feelings of all involved in this awkward situation. While Bucke was bewildered, the Smiths were embarrassed and angry. The embarrassment at Mary's behavior was evident as late as 1949, when Logan Pearsall Smith edited his mother's letters and in a footnote said simply that his sister had gone to study Italian art under Berenson's tutorship and married him a year after the death of her husband in 1899. This is essentially true but suggests nothing of the family anguish that was involved. Bertrand Russell comes closer to it when he says that Alys Pearsall Smith was "deeply ashamed of the fact that her sister had abandoned her husband for Berenson" and did not consent to know Berenson until after Mary had married him. ${ }^{66}$ Mary's parents, not unlike many who find themselves deeply disappointed in a child, lashed out, probably in a number of directions, at whatever influences they believed may have encouraged her waywardness. The presence of Dr. Bucke at this calamitous moment no doubt suggested to their minds one such source-Walt Whitman - and that would account for Robert Smith's questioning, after a decade of obvious esteem for Whitman, Bucke's "extreme admiration" of him (WWC 8:467).

Had Bucke been more forthcoming about Hannah Smith's comments on Walt, greater light might have been shed on the degree, if any, to which the family held Whitman responsible for Mary's actions. Hannah dreaded the scandal she was sure would follow, and she probably feared Bucke would take the story back to Philadelphia, via Camden. Though she continued to love her daughter with a fullness not to be denied, Hannah was horrified that Mary abandoned her children. Hannah was a devoted mother and, in a way that linked her to Whitman, revered motherhood above all other roles for women. ${ }^{67}$ It was she who raised Mary's daughters, acting as their legal guardian after Frank's death, sending them off only for short visits with their mother, who found this arrangement much to her liking, although even then she complained to her diary about the care they required ( $M B 48)$.

Mary proved an apt pupil, willing to immerse herself sufficiently to learn a great deal of Berenson's innovative method of identifying the artist of a given painting based on evidence intrinsic to the work rather than on the highly unreliable sources available. She wrote some treatises on Italian art, published under the name Mary Logan, and for many years was important to the work Berenson carried out at their 
Tuscan villa, I Tatti. Berenson makes few references to Whitman in his diaries and letters; when he does, they are only in passing and always connected to some remembrance of Mary's about her friendship with the poet. In the summer of 1955 his diary contains a reference to "Twelve Poems," a publication obviously issued in commemoration of the centenary of Leaves of Grass, which he notes seem to have been chosen

with the purpose of showing one phase ... of a frank, joyous sensuality, free from pruriency, from irony, from cynicism not only new in the still so puritanical, so sexually furtive and hypocritical New England of nearly one hundred years ago, but anywhere in the Western world.

The entry concludes: "He aged beautifully, as my wife, then a young girl, who saw a good deal of him, assured me, telling me in detail of his way of life." 68

Though Mary remained devoted to Berenson, she seemed incapable of being faithful and as early as 1894 was involved in an affair with a young sculptor, Hermann Obrist, and then in 1897 with a young English would-be philosopher, Wilfred Blaydes. When Alys and Bertrand Russell became engaged, she caused her sister untold agony by flirting so seductively with Bertie that he almost lost his head over her. She somewhat reluctantly settled down after Frank Costelloe's death in 1899 made it possible for her and Berenson to marry the following year. While she obviously delighted in telling Berenson and others of her early association with Whitman, she never again wrote to the poet. Her diary for March 1892, when Whitman lay slowly dying, reveals a woman ecstatically in love: "I shall never forget the charm of these days-not only for the awakening of my intellect . . . but because Bernhard looked in such and such a way, and spoke in sweet deep tones. . . . Ah how happy, how happy I am. Truly this is a marvelous year" (MB 49).

Nor was there ever any further word to Whitman from Robert, Hannah, or Alys. Logan wrote one more letter in which he seemed to be trying to ease the old poet's mind about the report he knew Bucke must have delivered. He writes that no fewer than three photographs of Whitman adorn one wall of the Smith home at Friday's Hill and serve as constant reminders of him. Referring to Mary, he offers a classic understatement, that she "has got tremendously interested in art-especially Italian art and means to make art criticism her life work." 69

Perhaps it would have been kinder of Bucke if he had downplayed the entire business of his poor reception at Grosvenor Road, but it was not his nature to do so. He was often highly excitable, especially when it came to Whitman, and he tended to feed Whitman's anxiety over slights, real and imagined, perhaps to better prove his own loyalty. It is pathetic, though, to find Whitman bravely trying to push aside his hurt, only to immediately press Traubel in an effort to learn if there is something about the estrangement that is being kept from him. At Horace's 
denial, Whitman utters a convoluted statement in which he attempts to find a resolution that will allow him to move to the next stage of mourning the lost friendship before finally dismissing it: "if what we can all guess is all we all know, then we all know nothing - then we are mystified alike" (WWC 8:403). With the full picture displayed, one wishes that Whitman had known that he was not in any way to blame for the estrangement.

\section{Hofstra University}

\section{NOTES}

1 See Richard Maurice Bucke, Medical Mystic: Letters of Dr. Bucke to Walt Whitman and His Friends, ed. Artem Lozynsky (Detroit: Wayne State University Press, 1977), and Horace Traubel, With Walt Whitman in Camden, 8:402. Traubel's With Walt Whitman in Camden volumes are as follows: vols. 1-3 (1906-1914; rpt. New York: Rowman and Littlefield, 1961); vols. 4-7 (Carbondale: Southern Illinois University Press, 1959-1992); vols. 8-9 (Oregon House, CA: W. L. Bentley, 1996). Hereafter abbreviated as $W W C$, with volume and page number.

2 Walt Whitman, The Correspondence, ed. Edwin Haviland Miller, 6 vols. (New York: New York University Press, 1961-1977), 5:223.

3 Letter from Smith, August 8, 1891, Library of Congress; Traubel, 8:533.

4 The image of Mary Whitall Smith is too often merely that of a dutiful Quaker; see Christina Davey, "Walt Whitman and the Quaker Woman," Walt Whitman Quarterly Review 16 (Summer 1998), 1-22.

5 WWC, 8:467; King Lear Act 3, Scene 4.

$6 W W C, 8: 467$.

7 Mary Berenson, A Self-Portrait from Her Letters $\mathcal{G}$ Diaries, ed. Barbara Strachey and Jayne Samuels (New York: W. W. Norton, 1983), 36. The lines are a slightly altered version of stanza five of "Song of the Open Road." Hereafter cited parenthetically as $M B$.

8 Barbara Strachey, Remarkable Relations, The Story of the Pearsall Smith Family (London: Victor Gollancz, 1980), 66.

9 Logan Pearsall Smith, Unforgotten Years (London: Constable, 1938), 81, 85. The chapter on Whitman originally appeared in the Atlantic Monthly 160 (November 1937) 568-572; see William White, "Logan Pearsall Smith on Walt Whitman: A Correction and Some Unpublished Letters," Walt Whitman Newsletter 4 (June 1958), 87-90.

10 Henry Bryan Binns, A Life of Walt Whitman (1905; rpt. New York: Haskell House, 1969), 302.

11 Walt Whitman, Daybooks and Notebooks, ed. William White (New York: New York University Press, 1978), 2:308; Corr, 3:321.

12 Mary Costelloe, letter to Whitman, November 12, 1884, Library of Congress.

13 Strachey, 67. When Robert Smith began to use Pearsall Smith as the family name (at about the time Mary went to Smith College) his wife chose to remain Hannah Whitall Smith in both her public and private life. 


\section{Strachey, 66.}

15 Evidently confusing Mrs. Smith with Mrs. Stafford, David S. Reynolds identifies Hannah Whitall Smith as "Susan" in his Walt Whitman's America (New York: Alfred Knopf, 1995), 552.

16 Logan Pearsall Smith, A Chime of Words: The Letters of Logan Pearsall Smith, ed. Edwin Tribble (New York: Ticknor \& Fields, 1984), 40.

17 Strachey, 68.

18 Unforgotten Years, 53-54.

19 The strength of the bond between Smith and Willard can be seen in Frances Willard, "Hannah Whitall Smith," Woman and Temperance (Hartford: Park Publishing, 1883), 195-207, and in Smith's introduction to Willard's autobiography, Glimpses of Fifty Years: The Autobiography of an American Woman (Chicago: H. J. Smith, 1889) v-x. See also Ruth Bordin, Frances Willard, A Biography (Chapel Hill: University of North Carolina Press, 1986) and Woman and Temperance: The Quest for Power and Liberty 1873-1900 (Philadelphia: Temple University Press, 1981).

$20 W W C, 8: 467$.

21 It is doubtful that in this Quaker neighborhood Whitman would have found a place to buy alcoholic drinks; the reference may have been to the use of individual flasks. WWC, 1:172.

22 Broadlands was the country home of Lord and Lady Mount Temple; it was a great social gathering place made available to evangelists at this time because of their enormous popularity.

23 Unforgotten Years, 26. In his remembrance of Whitman's visits Smith conjectures that Whitman's account of Elias Hicks might have been written while under the Smith roof, but Whitman wrote the sketch much later, in May of 1888; see Walt Whitman, Prose Works 1892, ed. Floyd Stovall (New York: New York University Press, 1964), 2:268.

24 Robert Allerton Parker, The Transatlantic Smiths (New York: Ramdon House, 1959), 5.

\section{Unforgotten Years, 80.}

26 George Santayana was at Harvard at the same time as Logan Pearsall Smith and Bernhard Berenson, where they were all, to varying degrees, proteges of Charles Eliot Norton. In 1894 Santayana had an intimate relationship with Earl Russell, the elder brother of Alys Smith Russell's husband, Bertrand Russell. See Douglass Shand-Tucci, The Art of Scandal (New York: Harper, 1997), 87. Unlike Bertrand Russell, Santayana was highly critical of Whitman's poetry, seeing it as the highest example of what he termed "the poetry of barbarism." See Interpretations of Poetry and Religion (New York: Scribner's, 1900), 169.

$27 W W C, 8: 468$.

28 Tribble, 42.

29 Strachey, 73; $D B N, 2: 398$.

30 Smith to Whitman, March 3, 1889, Library of Congress.

$31 W W C, 8: 468$. 
Unforgotten Years, 72.

33 Catalog of a Collection Containing Manuscripts and Rare Editions of Fames foyce, $A$ Few Manuscripts of Walt Whitman, and Two Drawings by William Blake, offered by Shakespeare and Company, 1922, from the possessions of Sylvia Beach, National Library, Dublin. For information on the Whitman manuscripts see Appendix to Notes.

34 Unforgotten Years, 92. Gosse's account of the visit does not corroborate Smith's account; see "A Note on Walt Whitman," The New Review 10 (April 1894), 447-457, and William White, "Sir Edmund Gosse on Walt Whitman," Victorian Studies 1 (December 1957), 180-182.

\section{$35 D B N, 2: 342$.}

36 Unforgotten Years, 124.

37 Tribble, 41. In January of the following year, another visit brought the interesting observation that Whitman's mind was "as clear as ever," but it seemed to Logan that "he was tired of being a poet and being literary and preferred new things and conversation that made no demands on his intellect" (41).

38 Strachey, 99.

39 WWC, 8:467.

40 Bertrand Russell, The Autobiography of Bertrand Russell, 1872-1914 (Boston: Little, Brown, 1915), 104.

41 Russell, 195.

42 The divorce allowed Russell to marry Dora Black, who was carrying his child.

43 Bertrand Russell, The Cambridge Essays 1888-89, ed. Kenneth Blackwell (London: George Allen \& Unwin, 1983), 1:62.

44 Cambridge Essays, 92.

45 Cambridge Essays, 401.

46 WWC, 8:468.

47 WWC, 3:334. While yet a lover of Leaves, Logan's literary tastes were already changing; he brought Whitman a copy of George Washington Cable's Madame Delphine (1881), which Whitman did not care for because of "the French delicacy" of its style; see $W W C, 1: 96$.

48 Unforgotten Years, 95. In an undated letter to his sister Mary, Logan claimed that reading Whitman changed his mind on many subjects, "especially the way I looked at stupid and vulgar people. Now they seem like beautiful souls temporarily uninviting in attire, of manners, habits, etc." See Tribble, 40.

49 Unforgotten Years, 93.

50 Logan Pearsall Smith, Words and Idioms, Studies in the English Language (London: Constable, 1925), 2.

51 Correspondence file, Library of Congress.

52 Gore Vidal, foreword to Logan Pearsall Smith, All Trivia (1934; rpt. New York: Ticknor \& Fields, 1984), xix. 
53 Unforgotten Years, 94.

54 Unforgotten Years, 94-95.

55. Autobiography of Bertrand Russell, 111.

56 Autobiography of Bertrand Russell, 122-124.

57 Alan Simpson, Artful Partners (New York: Macmillan, 1986), 51.

58 The relationship between Lady Somerset and Frances Willard, head of the American WCTU, was one of the strongest and most significant of a number of such relationships in Willard's life. See Bordin, Frances Willard, 199-200.

59 Robert Gathorne-Hardy, Recollections of Logan Pearsall Smith (New York: Macmillan, 1950), 113.

60 Strachey, 165-166.

$61 W W C, 8: 468$.

62 Costelloe to Whitman, January 17, 1887, Library of Congress.

63 Strachey and Samuels, 40. Mary did manage, in the summer of 1889 , to write a loving tribute to Whitman on the occasion of his seventieth birthday. She says that she has "learned to appreciate Mr. Whitman's work better in the four years I have been living in England" and that "the privilege of knowing Walt Whitman has always been one of the greatest privileges of my life." See Horace L. Traubel, ed., Camden's Compliment to Walt Whitman (Philadelphia: David McKay, 1889), 52-53.

64 Strachey, 110.

65 Strachey, 111.

66 Autobiography of Bertrand Russell, 112.

67 "Mother-love," as it was called, was important to women reformers in both England and the United States; Willard quotes Hannah Whitall Smith defining the WCTU as "organized mother-love." See Glimpses, 331. Though Willard was childless, in 1896 she published a book on the art of mothering through the WCTU. See Willard, $A$ Great Mother (Chicago: Woman's Christian Temperance Union, 1896).

68 Bernard Berenson, Sunset and Twilight, From the Diaries of 1947-1958, ed. Nicky Mariano (New York: Harcourt, Brace \& World, 1963), 399.

69 Smith to Whitman, August 8, 1891, Library of Congress. 